\title{
High expression of programmed cell death protein 1 on peripheral blood T-cell subsets is associated with poor prognosis in metastatic gastric cancer
}

\author{
BIAN SHI ${ }^{1}$, QIUJIAN LI ${ }^{1}$, XUHUI MA ${ }^{1}$, QILONG GAO ${ }^{1}, \mathrm{LU} \mathrm{LI}^{1}$ and JUNFENG CHU ${ }^{2}$ \\ Departments of ${ }^{1}$ Integrated Traditional Chinese and Western Medical Oncology, and ${ }^{2}$ Oncology, \\ Zhengzhou University Affiliated Cancer Hospital, Zhengzhou, Henan 450001, P.R. China
}

Received September 10, 2017; Accepted May 24, 2018

DOI: $10.3892 / \mathrm{ol} .2018 .9190$

\begin{abstract}
Immune checkpoints in solid tumors serve important roles in metastasis. The present study was designed to explore the expression of programmed cell death protein 1 (PD-1) on peripheral blood T-cell subsets and its role in the clinicopathological features and prognosis of patients with metastatic gastric cancer. The expression of PD-1 in peripheral blood T-cell subsets was detected in 100 metastatic gastric cancer patients prior to the first line chemotherapy by flow cytometric analysis. The potential associaton between the peripheral blood T-cell subsets PD-1 level and the clinicopathological features of patients with metastatic gastric cancer and the clinical outcomes was analyzed. The percent of high PD-1 expressed cluster of differentiation $(\mathrm{CD}) 3^{+}, \mathrm{CD}^{+} \mathrm{CD}^{+}$and $\mathrm{CD}^{+} \mathrm{CD}^{+} \mathrm{T}$-cells was $20.4,13.0$ and $9.4 \%$, respectively in patients with metastatic gastric cancer. The overall survival (OS) and progression-free survival (PFS) rate of the 100 patients with metastatic gastric cancer was 12.2 and 3.9 months, respectively. Kaplan-Meier curve with long-rank analysis indicated that patients with higher $\mathrm{PD}-1^{+} / \mathrm{CD}^{+}, \mathrm{PD} 1^{+} / \mathrm{CD} 3^{+} \mathrm{CD} 4^{+}$and $\mathrm{PD}-1^{+} / \mathrm{CD}^{+} \mathrm{CD}^{+}$ levels had a worse prognosis (all $\mathrm{P}<0.05)$. Univariate and multivariate analysis revealed that high $\mathrm{PD}-1^{+} / \mathrm{CD}^{+}$[hazard ratio (HR), 2.145; $\mathrm{P}=0.015]$, high $\mathrm{PD}-1^{+} / \mathrm{CD}^{+} \mathrm{CD}^{+}(\mathrm{HR}, 1.866$; $\mathrm{P}=0.034)$ and high $\mathrm{PD}-1^{+} / \mathrm{CD}^{+} \mathrm{CD}^{+}(\mathrm{HR}, 1.817 ; \mathrm{P}=0.033)$ level in peripheral blood were independent risk factors for predicting the survival time of patients with metastatic gastric cancer. High PD $-1^{+} / \mathrm{CD}^{+}$, high $\mathrm{PD}-1^{+} / \mathrm{CD}^{+}{ }^{+} \mathrm{CD}^{+}$and high $\mathrm{PD}-1^{+} / \mathrm{CD}^{+}{ }^{+} \mathrm{CD} 8^{+}$ expression conferred a lower overall survival rate in patients with metastatic gastric cancer. These results suggest that high PD-1 expression on peripheral blood T-cell subsets may potentially be novel prognostic biomarker for metastatic gastric cancer.
\end{abstract}

Correspondence to: Dr Junfeng Chu, Department of Oncology, Zhengzhou University Affiliated Cancer Hospital, 127 Dongming Road, Zhengzhou, Henan 450001, P.R. China

E-mail: chujf2008t@163.com

Key words: programmed cell death protein 1, T-cell subsets, prognostic markers, metastatic gastric cancer

\section{Introduction}

Gastric cancer is rampant in many countries around the world (1). According to Globocan 2012, gastric cancers rank as the 4th most common malignancy, accounting for more than $6.8 \%$ of adult malignancies; and the third leading cause of cancer death worldwide, accounting for more than $8.8 \%$ of adult malignancie; especially in China, gastric cancer causing approximately 325,000 deaths per year (2). It's well known that prognosis of gastric cancer remains poor due to the lack of effective therapies in patients with advanced cancer $(2,3)$.

Immunotherapy has become one of the most promising treatments in gastric cancer, especially immunotherapy targeting the immune checkpoints programmed cell death protein-1 (PD-1) and programmed death-ligand-1 (PD-L1) (4). PD-1, a cluster of differentiation (CD)28 family member, is an immunosuppressive receptor expressed on T cells, B cells, monocytes, natural killer cells (NKs) and many tumor-infiltrating lymphocytes (TILs) $(5,6)$. Previous studies have shown that high-PD-1/CD4 ratio was associated with poor prognosis in NSCLC patients (7); high proportion of PD $-1^{+} \mathrm{CD} 4^{+} \mathrm{T}$ cells in the peripheral blood cells of PDAC patients was correlated to chemotherapy resistance (8); high surface expression of $\mathrm{PD}-1^{+} \mathrm{CD} 8^{+} \mathrm{T}$ cells confered worse relapse-free and overall survival (OS) rates in patients with colorectal cancer (9); an overall low PD-1 and a concurrent high $\mathrm{CD}^{+} \mathrm{T}$ cells expression was found in high-risk prostate cancer tissue (10). All these results indicated that the surface expression of PD-1 on T-cells was tightly associated with the prognosis of cancer patients.

Recent studies have confirmed the expression of PD-1 and its relationship with prognosis in gastric cancer patients (11). In this study, we clarify the significance of PD-1 expression on peripheral blood T-cell subsets, then explore the relationships between PD-1 and the clinicopathological features and prognosis of patients with metastatic gastric cancer.

\section{Patients and methods}

Patients. A total of 100 outpatients with metastatic gastric cancer met the inclusion criteria from the Zhengzhou University Affiliated Cancer Hospital (Zhengzhou, China) 
were enrolled in the study between May 2015 and May 2016. The inclusion criteria were listed as follows: i) The diagnosis of metastatic gastric cancer was confirmed by endoscopic biopsy and imageological examination; ii) the disease was classified as pathologic M1 with any $\mathrm{T}$ and $\mathrm{N}$ stage based on the standard of the WHO Classification of Tumors of the Digestive System, 2010 edition (12,13); iii) $2 \mathrm{ml}$ peripheral blood was drawn before the first line therapy; iv) patients had completed 4 courses of first line chemotherapy as documented in the medical record; and v) complete follow-up data was available. This study was approved by the ethics committee at the Zhengzhou University Affiliated Cancer Hospital, and informed consent form was signed by every patient. The clinical characteristics of these patients were detailed in Table I.

Treatment and response. Oxaliplatin $\left(130 \mathrm{mg} / \mathrm{m}^{2} \mathrm{~d} 1\right.$, every 3 weeks) combined with Capecitabine (1,000 mg bid d1-14, every 3 weeks) was undergone as the first line chemothrapy. Therapeutic efficacy was evaluated every 2 cylcles of chemotherapy. The follow-up was performed until July 30, 2017. progression-free survival (PFS) was calculated from the date of first treatment to the date of progression or death/censoring. OS was calculated from the date of first treatment to the date of death or censoring. The therapy regimen was replaced when the patient emerged progressive disease.

Preparation of peripheral blood mononuclear cells (PBMCs). Approximately $40 \mathrm{ml}$ of peripheral blood was drawn from the patients on the day before surgery and on the day before the first line therapy. A Ficoll-Paque (Pharmacia, Uppsala, Sweden) density gradient was used to centrifuge blood samples.

Flow cytometric analysis. PBMC $\left(1 \times 10^{5}\right)$ were suspended in PBS supplemented with $20 \%$ human AB serum and incubated on ice with appropriate dilution of antibodies for $30 \mathrm{~min}$. All antibodies used in this study including anti-CD3-PE-Cy7, anti-CD4-PerCP-Cy5-5, anti-CD8-APC, anti-CD279 (PD-1)-FITC, were purchased from BioLegend (San Diego, CA, USA). APC mouse IgG1(j) (clone MOPC-21), PE-Cy7 mouse IgG2b(j) (clone MPC-11), PerCP-Cy5-5 mouse IgG1(j) (clone MOPC-21) and FITC mouse IgG2b(j) (clone 27-35; all BioLegend), were used as isotype controls. Additionally, FMO plus isotype controls were used to help us gate the negative and positive populations of CD3, CD4, CD8 and PD-1 (14). Briefly, when we run flowcytometry, we stained all antibodies to observe the expression of CD3, CD4, CD8 and PD-1, however, we also stained CD3, CD4, CD8 and FITC mouse IgG2b as FMO plus isotype control of PD-1 expression. The similar method was used to distinguish the negative and positive populations of CD3, CD4, and CD8. The staining cells were analyzed on BD FACS Canto II with FACS Diva software (BD Biosciences, Franklin Lakes, NJ, USA).

Statistical analysis. All statistical analyses were performed using SPSS 24.0 (IBM Corp., Armonk, NY USA). Difference between two groups was analyzed by student t-test, and difference between multiple groups was analyzed by one way ananlysis of variance with Tukey's post hoc test. Kaplan-Meier curve with the log rank test was used in survival analysis. Prognostic factors were examined by univariate and multivariate analysis on the basis of Cox proportional hazards model were used for. $\mathrm{P}<0.05$ was considered to indicate a statistically significant difference.

\section{Results}

Expression of PD-1 on peripheral blood lymphocytes. We detected the surface expression of PD-1 on lymphocytes from the PBMCs of patients with metastatic gastric cancer, and focused on the expression of PD- 1 on $\mathrm{CD}^{+}, \mathrm{CD}^{+} \mathrm{CD}^{+}$and $\mathrm{CD}^{+} \mathrm{CD}^{+} \mathrm{T}$-cell subsets. The representative staining patterns of PD-1 on these subsets were shown in Fig. 1. For further analysis, we defined that lymphocytes with $\mathrm{PD}-1^{+} / \mathrm{CD}^{+}>15 \%$, $\mathrm{PD}-1^{+} / \mathrm{CD}^{+} \mathrm{CD}^{+}>10 \%$, or $\mathrm{PD}-1^{+} / \mathrm{CD}^{+}{ }^{+} \mathrm{CD}^{+}>5 \%$ showed high surface $\mathrm{PD}-1$ expression on $\mathrm{T}$-cell subsets by using isotype-matched control, on the contrary PD-1 expression level is low. The percent of $\mathrm{CD}^{+}, \mathrm{CD}^{+} \mathrm{CD}^{+}$and $\mathrm{CD}^{+} \mathrm{CD}^{+}$ T-cells with high surface PD-1 expression were 20.4, 13.0 and $9.4 \%$, respectively.

Relationship between PD-1 expression on peripheral blood T-cell subsets and clinicopathological factors in metastatic gastric cancer. The correlation between PD-1 expression on peripheral blood T-cell subsets and clinicopathological factors of patients with metastatic gastric cancer was analyzed. However, no correlation was found between PD-1 expression on peripheral blood T-cell subsets and clinicopathological factors of patients with metastatic gastric cancer (all $\mathrm{P}>0.05$ ) (Table I).

Relationship between PD-1 expression on peripheral blood $T$-cell subsets and OS in metastatic gastric cancer. The correlation of PD-1 expression on peripheral blood T-cell subsets with the prognosis of patients with metastatic gastric cancer was analyzed. The OS and PFS rate of the 100 patients with metastatic gastric cancer were 12.2 and 3.9 months, respectively (Fig. 2). The 1-year and 2-year OS rates were 53.0 and $2 \%$, respectively.

Kaplan-Meier survival analysis revealed that patients with high $\mathrm{PD}-1^{+} / \mathrm{CD}^{+}, \mathrm{PD}^{-} 1^{+} / \mathrm{CD}^{+} \mathrm{CD}^{+}$, and $\mathrm{PD}-1^{+} / \mathrm{CD} 3^{+} \mathrm{CD} 8^{+}$ level showed worse prognosis compared with patients with low PD $-1^{+} / \mathrm{CD}^{+}, \mathrm{PD} 1^{+} / \mathrm{CD} 3^{+} \mathrm{CD} 4^{+}$, and $\mathrm{PD}-1^{+} / \mathrm{CD}^{+}{ }^{+} \mathrm{CD}{ }^{+}$level (all $\mathrm{P}<0.05$ ) (Fig. 3). Univariate analysis was performed to estimate the clinical significances of various parameters that may affect survival of patients with metastatic gastric cancer. As shown in Table II, Karnofsky performance score (KPS) scores [hazard ratio (HR); 2.059; $\mathrm{P}=0.043$ ], tumor differentiation $(\mathrm{HR}, 2.167$; $\mathrm{P}=0.031)$, number of metastatic organs $(\mathrm{HR}, 3.041 ; \mathrm{P}=0.032$ ), liver metastasis (HR, 3.234; $\mathrm{P}=0.047)$, peritoneal metastasis (HR, 2.567; $\mathrm{P}=0.038)$, high $\mathrm{PD}-1^{+} / \mathrm{CD}^{+}$level (HR, 2.066 ; $\mathrm{P}=0.005)$, high $\mathrm{PD}-1^{+} / \mathrm{CD}^{+} \mathrm{CD}^{+}$level $(\mathrm{HR}, 1.857 ; \mathrm{P}=0.028)$, and high $\mathrm{PD}-1^{+} / \mathrm{CD}^{+}{ }^{+} \mathrm{CD} 8^{+}$level $(\mathrm{HR}, 1.796 ; \mathrm{P}=0.023)$ were all predictive factors for prognosis of patients with metastatic gastric cancer. Then multivariate analysis based on Cox's proportional hazards model was performed to determine the independent prognostic factors for patients with metastatic gastric cancer in our cohort. The results indicated that high $\mathrm{PD}-1^{+} / \mathrm{CD}^{+}(\mathrm{HR}, 2.145 ; \mathrm{P}=0.015)$, high $\mathrm{PD}-1^{+} / \mathrm{CD}^{+}{ }^{+} \mathrm{CD} 4^{+}$ (HR, 1.866; $\mathrm{P}=0.034)$, and high $\mathrm{PD}-1^{+} / \mathrm{CD}^{+} \mathrm{CD}^{+}(\mathrm{HR}, 1.817$; $\mathrm{P}=0.033)$ level were independent risk factors for predicting the survival time of metastatic gastric cancer (Table III). 
Table I. Association between PD-1 expression on peripheral blood T-cell subsets and clinicopathological factors in patients with metastatic gastric cancer.

\begin{tabular}{|c|c|c|c|c|c|c|c|c|c|c|}
\hline \multirow[b]{2}{*}{ Characteristics } & \multirow[b]{2}{*}{ Case $(n=100)$} & \multicolumn{2}{|c|}{$\mathrm{PD}-1^{+} / \mathrm{CD}^{+}{ }^{+}$} & \multirow[b]{2}{*}{ P-value } & \multicolumn{2}{|c|}{$\begin{array}{c}\mathrm{PD}-1^{+} / \\
\mathrm{CD}^{+} \mathrm{CD}^{+}\end{array}$} & \multirow[b]{2}{*}{ P-value } & \multicolumn{2}{|c|}{$\begin{array}{c}\mathrm{PD}-1^{+} / \\
\mathrm{CD}^{+}{ }^{-} 8^{+}\end{array}$} & \multirow[b]{2}{*}{ P-value } \\
\hline & & High & Low & & High & Low & & High & Low & \\
\hline Total & 100 & 42 & 58 & 0.766 & 38 & 62 & 0.574 & 44 & 56 & 0.151 \\
\hline Male & 65 & 28 & 37 & & 26 & 39 & & 32 & 33 & \\
\hline Female & 35 & 14 & 21 & & 12 & 23 & & 12 & 23 & \\
\hline Age (years) & & & & 0.623 & & & 0.84 & & & 0.824 \\
\hline$\geq 60$ & 33 & 15 & 18 & & 13 & 20 & & 14 & 19 & \\
\hline$<60$ & 67 & 27 & 40 & & 25 & 42 & & 30 & 37 & \\
\hline KPS score & & & & 0.101 & & & 0.096 & & & 0.642 \\
\hline$\geq 80$ & 75 & 35 & 40 & & 32 & 43 & & 34 & 41 & \\
\hline$<80$ & 25 & 7 & 18 & & 6 & 19 & & 10 & 15 & \\
\hline Differentiation & & & & 0.06 & & & 0.324 & & & 0.967 \\
\hline Well & 18 & 4 & 14 & & 5 & 13 & & 8 & 10 & \\
\hline Poor & 82 & 38 & 44 & & 33 & 49 & & 36 & 46 & \\
\hline Number of metastatic organs & & & & 0.463 & & & 0.552 & & & 0.422 \\
\hline$>2$ & 41 & 19 & 22 & & 17 & 24 & & 20 & 21 & \\
\hline$\leq 2$ & 59 & 23 & 36 & & 21 & 38 & & 24 & 35 & \\
\hline Liver metastasis & & & & 0.654 & & & 0.709 & & & 0.627 \\
\hline Present & 45 & 20 & 25 & & 18 & 27 & & 21 & 24 & \\
\hline Absent & 55 & 22 & 33 & & 20 & 35 & & 23 & 32 & \\
\hline Peritoneal metastasis & & & & 0.609 & & & 0.638 & & & 0.594 \\
\hline Present & 47 & 21 & 26 & & 19 & 28 & & 22 & 25 & \\
\hline Absent & 53 & 21 & 32 & & 19 & 34 & & 22 & 31 & \\
\hline
\end{tabular}

PD-1, programmed cell death protein 1; CD, cluster of differentiation; KPS, Karnofsky performance score.
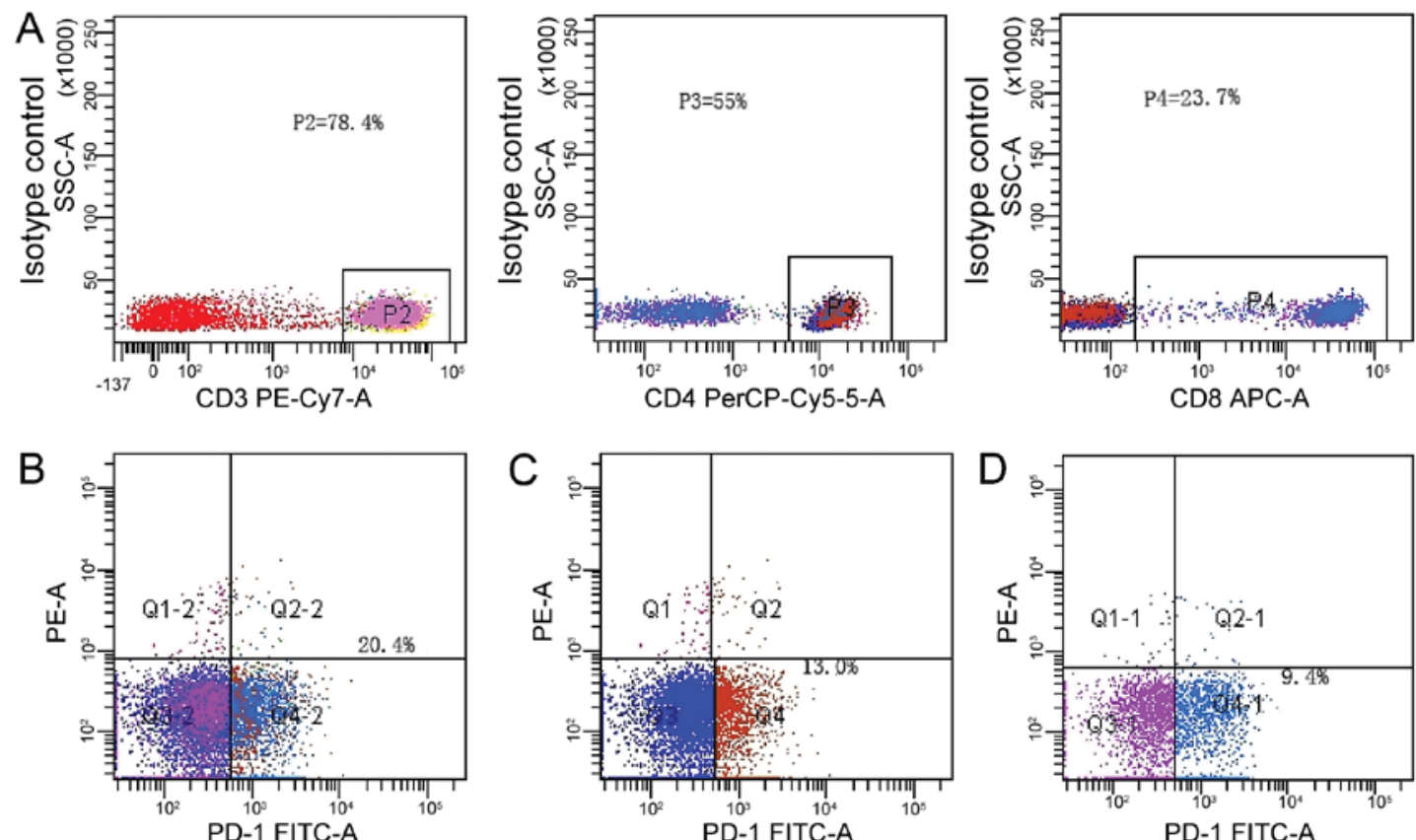

Figure 1. Representative staining patterns of PD-1 on peripheral blood T-cell subsets from PBMC of patients with metastatic gastric cancer. (A) The baseline for the PD-1 staining was determined using an isotype-matched control. The expression of (B) PD- $1^{+} / \mathrm{CD} 3^{+},(\mathrm{C}) \mathrm{PD}-1^{+} / \mathrm{CD} 3^{+} \mathrm{CD} 4^{+}$and $(\mathrm{D}) \mathrm{PD}-1^{+} / \mathrm{CD} 3^{+} \mathrm{CD} 8^{+}$ from PBMC of patients with metastatic gastric cancer. $\mathrm{CD}$, cluster of differentiation; PD-1, programmed cell death protein 1; BMC, peripheral blood mononuclear cells. 
Table II. Univariate analysis of clinicopathological factors for overall survival in gastric cancer.

\begin{tabular}{|c|c|c|c|}
\hline Parameters & Hazard ratio & $95 \%$ confidence interval & P-value \\
\hline Age ( $\geq 60$ vs. $<60$ years $)$ & 1.885 & $1.024-3.895$ & 0.067 \\
\hline Sex (male vs. female) & 1.603 & $0.876-4.563$ & 0.168 \\
\hline KPS score ( $\geq 8$ vs. $<80)$ & 2.059 & $1.556-6.345$ & 0.043 \\
\hline Differentiation (well vs. poor) & 2.167 & $1.543-4.324$ & 0.031 \\
\hline Number of metastatic organs ( $<2$ vs. $\leq 2$ ) & 3.041 & $2.123-7.342$ & 0.032 \\
\hline Liver metastasis (present vs. absent) & 3.234 & $2.246-9.213$ & 0.047 \\
\hline Peritoneal metastasis (present vs. absent) & 2.567 & $1.526-5.563$ & 0.038 \\
\hline PD $-1^{+} / \mathrm{CD}^{+}$(high vs. low) & 2.066 & $1.311-3.257$ & 0.005 \\
\hline $\mathrm{PD}-1^{+} / \mathrm{CD} 3^{+} \mathrm{CD}^{+}{ }^{+}$(high vs. low) & 1.857 & $1.171-2.946$ & 0.028 \\
\hline $\mathrm{PD}-1^{+} / \mathrm{CD} 3^{+} \mathrm{CD} 8^{+}$(high vs. low) & 1.796 & $1.159-2.784$ & 0.023 \\
\hline
\end{tabular}

PD-1, programmed cell death protein 1; CD, cluster of differentiation; KPS, Karnofsky performance score.
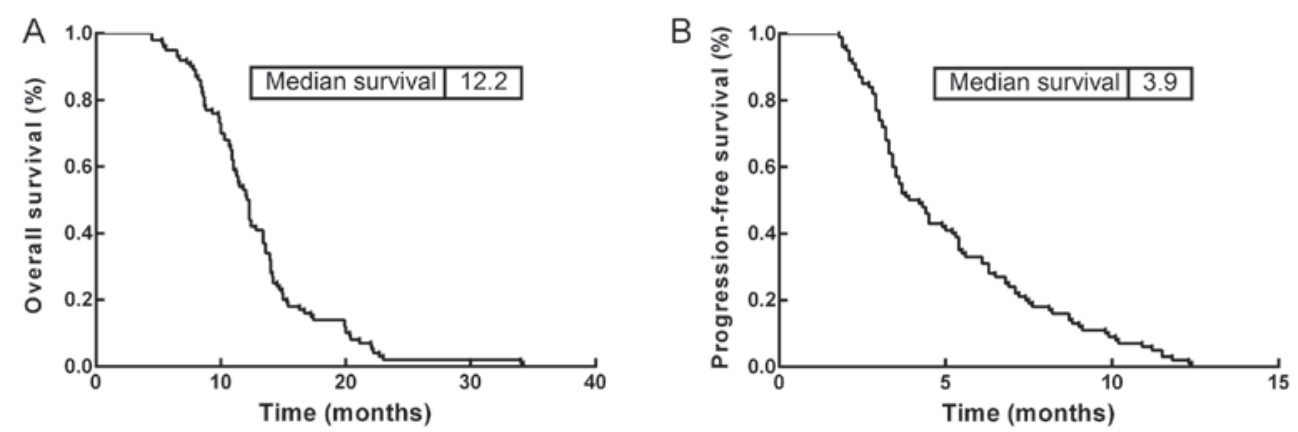

Figure 2. Survival of patients with metastatic gastric cancer following first line therapy. Kaplan-Meier survival curves showed the (A) overall survival and (B) progression-free survival of metastatic gastric cancer patients following the first line therapy.

A

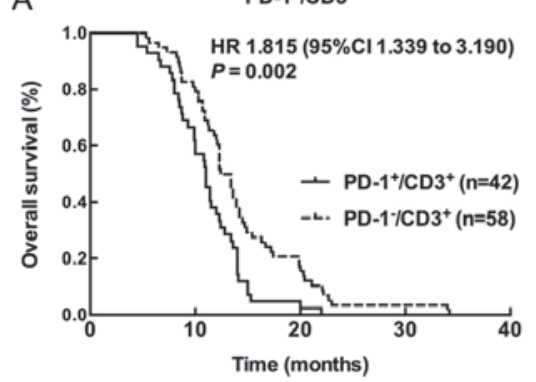

B

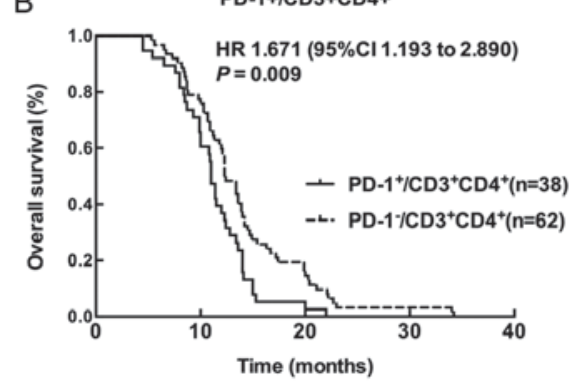

C

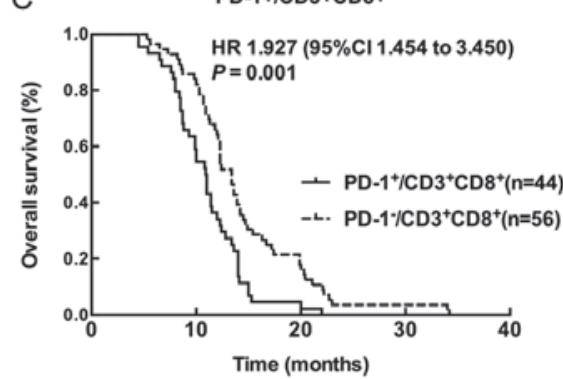

Figure 3. OS of metastatic gastric cancer patients following first line therapy. (A) Kaplan-Meier survival curves with log-rank method showed the OS of patients with metastatic gastric cancer following first line therapy (high PD- $1^{+} / \mathrm{CD} 3^{+}$vs. low PD- $1^{+} / \mathrm{CD} 3^{+}$). (B) Kaplan-Meier survival curves with log-rank method showed the OS of patients with metastatic gastric cancer following first line therapy (high PD- $1^{+} / \mathrm{CD} 3^{+} \mathrm{CD} 4^{+}$vs. low PD- $1^{+} / \mathrm{CD} 3^{+} \mathrm{CD} 4^{+}$). $(\mathrm{C}) \mathrm{Kaplan}-\mathrm{Meier}$ survival curves with the log-rank method revealed the OS of patients with metastatic gastric cancer from first line therapy $\left(\right.$ high $\mathrm{PD}-1^{+} / \mathrm{CD} 3^{+} \mathrm{CD} 8^{+} \mathrm{vs}$. low $\left.\mathrm{PD}-1^{+} / \mathrm{CD}^{+} \mathrm{CD}^{+}\right)$. OS, overall survival; PD-1, programmed cell death protein 1; CD, cluster of differentiation; HR, hazard ratio.

Furthermore, we compared the prognostic value of PD-1 expression on peripheral blood T-cell subsets for OS with that of other independent prognostic factors using receiver operating characteristics (ROC) curves, which showed that the $\mathrm{PD}-1^{+} / \mathrm{CD}^{+}$expression was not different from $\mathrm{PD}-1^{+} / \mathrm{CD}^{+}{ }^{+} \mathrm{CD} 4^{+}$with regards to OS, and the $\mathrm{PD}-1^{+} / \mathrm{CD} 3^{+} \mathrm{CD} 4^{+}$ expression was not different from $\mathrm{PD}-1^{+} / \mathrm{CD}^{+} \mathrm{CD} 8^{+}$with regards to OS (Fig. 4). Interestingly, when we compared $\mathrm{PD}-1^{+} / \mathrm{CD}^{+}$with $\mathrm{PD}-1^{+} / \mathrm{CD}^{+}{ }^{+} \mathrm{CD} 8^{+}$, the $\mathrm{PD}-1^{+} / \mathrm{CD}^{+} \mathrm{CD} 8^{+}$had a better prognostic value than $\mathrm{PD}-1^{+} / \mathrm{CD}^{+}$(Fig. 4).

\section{Discussion}

Recently, immunotherapy has become a promising treatment for many types of cancers, including gastric cancer, which has given rise to a growing interest in cancer immunotherapy (15). Many clinical trials have demonstrated that anti-PD-1 therapy was a successful treatment for malignancies, including NSCLC, metastatic melanoma, renal cell carcinoma, Hodgkin's lymphoma, and metastatic gastric cancer (16-18). It has been indicated that PD-1 and PD-L1 expression were 
Table III. Multivariate analysis of clinicopathological factors for disease special survival in gastric cancer.

\begin{tabular}{lccc}
\hline Parameters & Hazard ratio & 95\% confidence interval & P-value \\
\hline KPS score ( $\geq 8$ vs. $<80)$ & 1.767 & $1.543-6.324$ & 0.131 \\
Differentiation (well vs. poor) & 1.159 & $0.756-4.345$ & 0.243 \\
Number of metastatic organs (>2 vs. $\leq 2)$ & 2.041 & $1.123-7.342$ & 0.126 \\
Liver metastasis (present vs. absent) & 2.289 & $2.239-11.213$ & 0.147 \\
Peritoneal metastasis (present vs. absent) & 2.136 & $1.238-8.175$ & 0.264 \\
PD- $1^{+} / \mathrm{CD}^{+}$(high vs. low) & 2.145 & $1.325-5.232$ & 0.015 \\
PD- $1^{+} / \mathrm{CD}^{+} \mathrm{CD}^{+}$(high vs. low) & 1.866 & $1.273-3.243$ & 0.034 \\
$\mathrm{PD}^{+}{ }^{+} / \mathrm{CD}^{+} \mathrm{CD}^{+}$(high vs. low) & 1.817 & $1.099-3.675$ & 0.033
\end{tabular}

PD-1, programmed cell death protein 1; CD, cluster of differentiation; KPS, Karnofsky performance score.

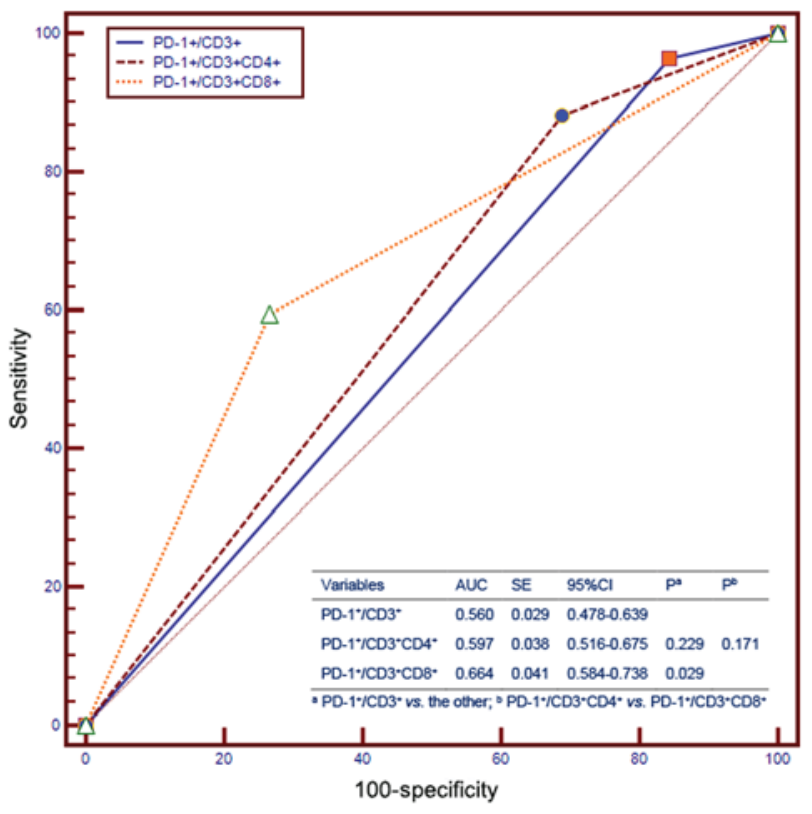

Figure4.Difference of prognostic value among PD-1+/CD3+,PD-1+/CD3+CD4+, and PD-1+/CD3+CD8+. Receiver operating characteristics curves for overall survival. P-values show the area under the receiver operating characteristics among the PD-1+/CD3+, PD-1+/CD3+CD4+, and PD-1+/CD3+CD8+. PD-1, programmed cell death protein $1 ; \mathrm{CD}$, cluster of differentiation; AUC, area under the curve; $\mathrm{SE}$, standard error; $\mathrm{Cl}$, confidence interval.

independent prognosis factors in gastric cancer by immunohistochemistry (IHC) analysis (19-22). Since it is difficult to get fresh specimens from patients to determine the expression of PD-1 or PD-L1 expression by IHC, no uniform standard was defined for PD-L1 positivity up to now. Eto et al defined PD-L1 positivity by staining of the tumor-cell in four grade: 6-25, $26-50$ or $51-75$ and $76-100 \%$ of cells $(12,23-29)$; Ti Wen and co-worker defined staining pattern of PD-L1 as positive if $<5$ or $\geq 5 \%$ in tumor cells (13); whereas Wenfeng Fang assessed the expression of PD-L1 by semi-quantitative $\mathrm{H}$-score and defined cases with greater than $10 \%$ PD-L1 expression on tumor cells were considered positive (26). Therefore, consistency detection of PD-1 and PD-L1 expression by IHC is limited due to the difference of antibody qualities from different manufacturers, the interpretative subjectivity, and the different standard on positivity thresholds.
For the development of new treatment modalities, the co-development of novel convenient detection methods of biomarkers is important. Here, we detected PD-1 expression in PBMC from patients with metastatic gastric cancer using flow cytometry analysis, which was an antibody-independent assay for PD-1 protein detection of circulation. To analysis the role of the expression level of PD-1 on peripheral blood T-cell subsets in clinicopathological factors and prognosis of patients with metastatic gastric cancer, we defined that lymphocytes with PD $-1^{+} / \mathrm{CD}^{+}>15 \%$, $\mathrm{PD}-1^{+} / \mathrm{CD}^{+} \mathrm{CD}^{+}>10 \%$, or $\mathrm{PD}-1^{+} / \mathrm{CD}^{+} \mathrm{CD}^{+}>5 \%$ showed high PD-1 expression level on T-cell subsets, on the contrary PD-1 expression level is low. However, our data indicated that there was no significant difference on the expression level of PD-1 on peripheral blood T-cell subsets between patients with high $\mathrm{PD}-1^{+} / \mathrm{CD}^{+}$, PD $-1^{+} / \mathrm{CD}^{+} \mathrm{CD}^{+}, \mathrm{PD}-1^{+} / \mathrm{CD}^{+} \mathrm{CD}^{+}$expression and patients with low PD $-1^{+} / \mathrm{CD}^{+}, \mathrm{PD}^{-} 1^{+} / \mathrm{CD}^{+} \mathrm{CD}^{+}, \mathrm{PD}-1^{+} / \mathrm{CD}^{+}{ }^{+} \mathrm{CD} 8^{+}$ expression.

In addition, the expression of PD-1 showed no correlation with clinicopathological factors of patients with metastatic gastric cancer. Then, we analyzed the correlation between $\mathrm{PD}-1^{+} / \mathrm{CD}^{+}, \mathrm{PD}^{-} 1^{+} / \mathrm{CD}^{+}{ }^{+} \mathrm{CD} 4^{+}, \mathrm{PD}-1^{+} / \mathrm{CD} 3^{+} \mathrm{CD} 8^{+}$expression and PFS, the data demonstrated that patients with high PD $-1^{+} / \mathrm{CD}^{+}$, PD $-1^{+} / \mathrm{CD} 3{ }^{+} \mathrm{CD} 4^{+}, \mathrm{PD}-1^{+} / \mathrm{CD} 3^{+} \mathrm{CD}^{+}$level showed worse OS. Further multivariate analysis using Cox's proportional hazards model indicated that high $\mathrm{PD}-1^{+} / \mathrm{CD}^{+}$, $\mathrm{PD}-1^{+} / \mathrm{CD}^{+}{ }^{+} \mathrm{CD} 4^{+}$, and $\mathrm{PD}-1^{+} / \mathrm{CD}^{+} \mathrm{CD}^{+}$were independent risk factors for predicting the survival of metastatic gastric cancer.

Furthermore, ROC analysis suggested that PD $-1^{+} / \mathrm{CD}^{+} \mathrm{CD} 4^{+}$ expression has a similar survival predictive ability as $\mathrm{PD}-1^{+} / \mathrm{CD} 3$ and $\mathrm{PD}-1^{+} / \mathrm{CD}^{+} \mathrm{CD}^{+}$, while $\mathrm{PD}-1^{+} / \mathrm{CD}^{+} \mathrm{CD}^{+}$higher predictive ability than $\mathrm{PD}-1^{+} / \mathrm{CD} 3$, implying that identification of $\mathrm{PD}-1^{+} / \mathrm{CD}^{+} \mathrm{CD}^{+}$in patients might be a more straightforward procedure.

Cumulative studies revealed that PD-L1 was widely expressed in human malignancies and was a component of the immunosuppressive microenvironment (24). A problems that cannot be neglected is that the heterogeneity of fresh specimens and peripheral blood. It was not clear the status of PD-1 expression on peripheral blood accurately reflect the status of PD-1 expression in tumor microenvironment. However, tumor-derived DNA and RNA can be released 
and circulated in the peripheral circulation of cancer patients, which operationally allowing for non-invasive gene expression profiling by body fluid analysis. Indeed, there is a wealth of information indicating a correlation between tumor-associated changes in genomic, epigenetic, or transcriptional patterns and alterations in the levels of cell-free circulating nucleic acids (cfCNAs) $(30,31)$. Thus, detected PD-L1 in peripheral blood may after all be accepted as a kind of practical methods for prostraction of disease progression. In the other hands, although we did not determined the expression of PD-L1 and PD-L2, two ligands for PD-1, on peripheral blood $\mathrm{T}$-cell subsets in the present study, it has been already demonstrated that PD-L1 expression in gastric cancer cells was significantly correlated with worse prognosis in gastric cancer patients (32). As to PD-L2, which deliver co-inhibitory signal by binding to PD-1, it is very interesting to determine PD-L2 expression on peripheral blood T-cell subsets to see its role on immune evasion in gastric cancer patients.

In conclusion, in our cohort, PD-1 expression on peripheral blood T-cell subsets is an independent prognostic factor in metastatic gastric cancer, suggest that PD-1 expression in peripheral blood T-cell subsets may potential be a novel prognostic marker for gastric cancer patients at advanced stage.

\section{Acknowledgements}

The authors would like to thank Dr Weiquan Lu (Department of Cancer Prevention, Henan Cancer Hospital, Changsha, China) for his assistance with statistical analysis.

\section{Funding}

No funding was received.

\section{Availability of data and materials}

The datasets used and/or analyzed during the current study are available from the corresponding author on reasonable request.

\section{Authors' contributions}

JC had full access to all of the data in the study and takes responsibility for the integrity of the data and the accuracy of the data analysis. BS performed the clinical analysis, including patient selection, tissue procurement, histology, patient case collection and biostatistics. QL and XM performed the data analysis and interpretation of results. BS and QG performed the experiments and statistical analysis. JC and LL planned and supervised the project, performed data analysis and wrote the manuscript. All authors have read and approved the final manuscript.

\section{Ethics approval and consent to participate}

The present study was approved by the Ethics Committee at Zhengzhou University Affiliated Cancer Hospital (Henan, China) and written informed consent was obtained from each patient.

\section{Consent for publication}

Written informed consent was obtained from all patients for the publication of their data.

\section{Competing interests}

The authors declare that they have no competing interests.

\section{References}

1. Hamamoto Y: Complications in advanced or recurrent gastric cancer patients with peritoneal metastasis during and after palliative systemic chemotherapy. Mol Clin Oncol 3: 539-542, 2015.

2. Chen W, Zheng R, Baade PD, Zhang S, Zeng H, Bray F, Jemal A, Yu XQ and He J: Cancer statistics in China, 2015. CA Cancer J Clin 66: 115-132, 2016.

3. Ferlay J, Soerjomataram I, Dikshit R, Eser S, Mathers C, Rebelo M, Parkin DM, Forman D and Bray F: Cancer incidence and mortality worldwide: Sources, methods and major patterns in GLOBOCAN, 2012. Int J Cancer 136: E359-E386, 2015.

4. Price TJ, Shapiro JD, Segelov E, Karapetis CS, Pavlakis N, Van Cutsem E, Shah MA, Kang YK and Tebbutt NC: Management of advanced gastric cancer. Expert Rev Gastroenterol Hepatol 6: 199-209, 2012.

5. Topalian SL, Taube JM, Anders RA and Pardoll DM: Mechanism-driven biomarkers to guide immune checkpoint blockade in cancer therapy. Nat Rev Cancer 16: 275-287, 2016.

6. Freeman GJ, Long AJ, Iwai Y, Bourque K, Chernova T, Nishimura H, Fitz LJ, Malenkovich N, Okazaki T, Byrne MC, et al: Engagement of the PD-1 immunoinhibitory receptor by a novel B7 family member leads to negative regulation of lymphocyte activation. J Exp Med 192: 1027-1034, 2000.

7. Latchman Y, Wood CR, Chernova T, Chaudhary D, Borde M, Chernova I, Iwai Y, Long AJ, Brown JA, Nunes R, et al: PD-L2 is a second ligand for PD-1 and inhibits T cell activation. Nat Immunol 2: 261-268, 2001.

8. Zheng H, Liu X, Zhang J, Rice SJ, Wagman M, Kong Y, Zhu L, Zhu J, Joshi M and Belani CP: Expression of PD-1 on CD4+ T cells in peripheral blood associates with poor clinical outcome in non-small cell lung cancer. Oncotarget 7: 56233-56240, 2016.

9. Komura T, Sakai Y, Harada K, Kawaguchi K, Takabatake H, Kitagawa H, Wada T, Honda M, Ohta T, Nakanuma Y and Kaneko S: Inflammatory features of pancreatic cancer highlighted by monocytes/macrophages and CD4+ T cells with clinical impact. Cancer Sci 106: 672-686, 2015.

10. Shibutani M, Maeda K, Nagahara H, Fukuoka T, Nakao S, Matsutani S, Hirakawa K and Ohira M: The prognostic significance of the tumor-infiltrating programmed cell death- $1^{+}$to $\mathrm{CD} 8^{+}$ lymphocyte ratio in patients with colorectal cancer. Anticancer Res 37: 4165-4172, 2017.

11. Baas W, Gershburg S, Dynda D, Delfino K, Robinson K, Nie D, Yearley JH and Alanee S: Immune characterization of the programmed death receptor pathway in high risk prostate cancer. Clin Genitourin Cancer 15: 577-281, 2017.

12. Yuan J, Zhang J, Zhu Y, Li N, Tian T, Li Y, Li Y, Li Z, Lai Y, Gao J and Shen L: Programmed death-ligand-1 expression in advanced gastric cancer detected with RNA in situ hybridization and its clinical significance. Oncotarget 7 : 39671-39679, 2016.

13. Eto S, Yoshikawa K, Nishi M, Higashijima J, Tokunaga T, Nakao T, Kashihara H, Takasu C, Iwata T and Shimada M: Programmed cell death protein 1 expression is an independent prognostic factor in gastric cancer after curative resection. Gastric Cancer 19: 466-471, 2016.

14. Vali B, Jones RB, Sakhdari A, Sheth PM, Clayton K, Yue FY, Gyenes G, Wong D, Klein MB, Saeed S, et al: HCV-specific T cells in HCV/HIV co-infection show elevated frequencies of dual Tim-3/PD-1 expression that correlate with liver disease progression. Eur J Immunol 40: 2493-2505, 2010.

15. Lauwers GY CF and Graham DY: Curado MP tumours of the stomach. In: WHO classification of tumours of the digestive system Bosman FT CF, Hruban RH, Theise ND (ed.), pp48-59, 2010 . 
16. Aldarouish $\mathrm{M}$ and Wang $\mathrm{C}$ : Trends and advances in tumor immunology and lung cancer immunotherapy. J Exp Clin Cancer Res 35: 157, 2016.

17. Dougan M and Dranoff G: Immune therapy for cancer. Annu Rev Immunol 27: 83-117, 2009.

18. Sharon E, Streicher H, Goncalves P and Chen HX: Immune checkpoint inhibitors in clinical trials. Chin J Cancer 33 434-444, 2014.

19. Ansell SM, Lesokhin AM, Borrello I, Halwani A, Scott EC, Gutierrez M, Schuster SJ, Millenson MM, Cattry D, Freeman GJ, et al: PD-1 blockade with nivolumab in relapsed or refractory Hodgkin's lymphoma. N Engl J Med 372: 311-319, 2015.

20. Brahmer JR, Hammers H and Lipson EJ: Nivolumab: Targeting PD-1 to bolster antitumor immunity. Future Oncol 11: 1307-1326, 2015.

21. Muro K, Chung HC, Shankaran V, Geva R, Catenacci D, Gupta S, Eder JP, Golan T, Le DT, Burtness B, et al: Pembrolizumab for patients with PD-L1-positive advanced gastric cancer (KEYNOTE-012): A multicentre, open-label, phase 1b trial Lancet Oncol 17: 717-726, 2016.

22. Rizvi NA, Mazières J, Planchard D, Stinchcombe TE, Dy GK Antonia SJ, Horn L, Lena H, Minenza E, Mennecier B, et al: Activity and safety of nivolumab, an anti-PD-1 immune checkpoint inhibitor, for patients with advanced, refractory squamous non-small-cell lung cancer (CheckMate 063): A phase 2, single-arm trial. Lancet Oncol 16: 257-265, 2015.

23. Böger C, Behrens HM, Mathiak M, Krüger S, Kalthoff $\mathrm{H}$ and Röcken C: PD-L1 is an independent prognostic predictor in gastric cancer of Western patients. Oncotarget 7: 24269-24283, 2016.

24. Fang W, Chen Y, Sheng J,Zhou T, Zhang Y,Zhan J, Liu L, Huang J, Peng $\mathrm{P}$ and Zhang L: Association between PD-L1 expression on tumour-infiltrating lymphocytes and overall survival in patients with gastric cancer. J Cancer 8: 1579-1585, 2017.
25. Saito R, Abe H, Kunita A, Yamashita H, Seto Y and Fukayama M: Overexpression and gene amplification of PD-L1 in cancer cells and PD-L1+ immune cells in Epstein-Barr virus-associated gastric cancer: The prognostic implications. Mod Pathol 30: 427-439, 2017.

26. Wen T, Wang Z, Li Y, Li Z, Che X, Fan Y, Wang S, Qu J, Yang X, Hou $\mathrm{K}$, et al: A four-factor immunoscore system that predicts clinical outcome for stage II/III gastric cancer. Cancer Immunol Res 5: 524-534, 2017.

27. Zhang L, Qiu M, Jin Y, Ji J, Li B, Wang X, Yan S, Xu R and Yang D: Programmed cell death ligand 1 (PD-L1) expression on gastric cancer and its relationship with clinicopathologic factors. Int J Clin Exp Pathol 8: 11084-11091, 2015

28. Zhang M, Dong Y, Liu H, Wang Y, Zhao S, Xuan Q, Wang Y and Zhang Q: The clinicopathological and prognostic significance of PD-L1 expression in gastric cancer: A meta-analysis of 10 studies with 1,901 patients. Sci Rep 6: 37933, 2016.

29. Wu Y, Cao D, Qu L, Cao X, Jia Z, Zhao T, Wang Q and Jiang J: PD-1 and PD-L1 co-expression predicts favorable prognosis in gastric cancer. Oncotarget 8: 64066-64082, 2017.

30. Brown JA, Dorfman DM, Ma FR, Sullivan EL, Munoz O, Wood CR, Greenfield EA and Freeman GJ: Blockade of programmed death-1 ligands on dendritic cells enhances $\mathrm{T}$ cell activation and cytokine production. J Immunol 170: 1257-1266, 2003.

31. Dong $\mathrm{H}$ and Chen L: B7-H1 pathway and its role in the evasion of tumor immunity. J Mol Med (Berl) 81: 281-287, 2003.

32. Schwarzenbach H, Hoon DS and Pantel K: Cell-free nucleic acids as biomarkers in cancer patients. Nat Rev Cancer 11: 426-437, 2011.

This work is licensed under a Creative Commons Attribution-NonCommercial-NoDerivatives 4.0 International (CC BY-NC-ND 4.0) License. 